\title{
Charting the origins, current status and new directions within Pacific/Pasifika education in Aotearoa New Zealand
}

Tanya Wendt Samu

\section{University of Auckland}

This essay charts (and critiques) the formal education of Pacific-heritage peoples in Aotearoa New Zealand. As a diverse minority group, the education of Pacific-heritage peoples has been an explicit strategic priority for the Ministry of Education for over two decades, although the provision and experience of education for and by Pacific-heritage peoples in this country has, at the very least, a fifty year whakapapa. The author traces the current position of Pacific peoples using a broad sociohistorical lens anchored in post-structural analysis principles, with an indigenous Pacific philosophical cast, in order to present a critique of the past that illuminates the present. Why is this important? The author argues that a deepened knowledge of such developments is an imperative for informed decision making in policy and practice, and for the research that should inform both.

Keywords: Pasifika/Pacific, policy, historical development, socio-historical context

\section{Introduction}

An important component of my research platform are my efforts to examine Pasifika/Pacific education policy that targets Pacific-heritage peoples in Aotearoa New Zealand and trace the knowledge and ideas about them that appear to have informed such policies. This requires an appreciation of the wider social, historical, economic and political context in which such knowledges and understandings are produced. In order to provide a degree of illustrative insight, this essay is organised as follows. First, a brief discussion of the theoretical principles which anchored the analysis this essay draws on is presented, followed by an explanation for the term the essay will use to refer to Pacificheritage peoples. The essay then details the findings of the analysis, before insights for "Why is this important?" are shared and justified.

\section{Theoretical positioning: Reading stars and swells}

The approach that I take is influenced by a deeply embedded cultural orientation regarding knowledge, space and time - that the present is inextricably connected to a dynamic (not deceased) past and, when understood and harnessed well, positions us for moving forward with confidence into the future. This is captured metaphorically by the following statement by Hawaiian master navigator and way-finder Nainoa Thompson: ${ }^{1}$

You only know where you are in this kind of navigation by memorising where you sailed from.

\footnotetext{
${ }^{1}$ http://pvs.kcc.hawaii.edu/ike/hookele/on_wayfinding.html
} 
The other influence on the approach that I take are Michel Foucault's ideas relating to the archaeology of knowledge (2002). He referred to the tracing of ideas, or the study of rhetoric (through time and space), as the historical analysis of ideas. He was concerned with how rhetoric could be studied and understood in relation to power and knowledge. These ideas and inherent processes have been named post-structural discourse analysis (Sawyer, 2002). Bacchi and Goodwin (2016) argued that policy is a form of discourse, and developed their approach to post-structural policy analysis accordingly. In terms of overall theoretical principles, post-structural policy analysis positions this component of my research platform.

\section{Who are the contemporary voyagers? And where are they?}

If one takes a macro-perspective of national policy and planning, two features, arguably, of Aotearoa New Zealand's Pacific-heritage population stand out. The first is its profile. This population is diverse, with more than thirty identifiable groups within Aotearoa New Zealand (Auckland City Council). ${ }^{2}$ Census New Zealand collects data on seven main island groups - Samoan, Tongan, Cook Islands, Niue, Fiji, Tokelau and Tuvalu. The Pacificheritage population is also very youthful - with the median age at the 2018 census being 23.4 years, compared to 41.4 years for European. It is growing faster than other groups in Aotearoa New Zealand, in terms of natural increase. In the 1996 census, Pacific peoples made up $5 \%$ of the total population of Aotearoa New Zealand, with 202,233. By 2006, the proportion was $6.9 \%$ of the total population. By 2018, it was $8.1 \%$, with 381,642 peoples. The majority of Pacific peoples live in the main urban areas of Aotearoa New Zealand, with $64 \%$ living in Auckland (Auckland City Council). ${ }^{3}$

The second stand out feature was articulated by Samu et al. (2008) when the state's response to the education and development of Pacific peoples was by then highly strategic and policy driven:

For Pacific peoples, the dominant influences on education policies are the knowledge economy discourse and their own demographic and socioeconomic location in New Zealand. Compared with other nations of the OECD, New Zealand shows relative weakness, which places economic competitiveness at risk (OECD, 2005). Focused education policy on Pasifika is not surprising, given that New Zealand's economic development could be adversely affected, especially in the Auckland region, if their education success rates are not improved. (p. 151)

There have been shifts over time in the formal terms used to refer to Pacific peoples. Terms such as 'Pacific Polynesian,' 'Pacific Island' and 'Pacific Islander' were used through the 1970s and into the 1980s. For a while in the 1990s, some education entities used 'Pacific nations peoples.' Then there was a discernible shift to 'Pasifika' within the Ministry of Education (MoE) and some Colleges of Education. This term became formalised in the early $21^{\text {st }}$ century (Samu, 2010) as evidenced by the MoE's first Pasifika Education Plan (2001) and Pasifika Development, a stand-alone faculty in the former Auckland College of Education.

\footnotetext{
${ }^{2}$ https://www.aucklandcouncil.govt.nz/plans-projects-policies-reports-bylaws/our-plansstrategies/auckland-plan/about-the-auckland-plan/Pages/pacificauckland.aspx\#: : :text=The\%202018\%20Census\%20recorded $\% 20$ a,per\%20 cent $\%$ 20lived $\% 20$ in $\% 20$ Auckl and.

${ }^{3}$ https://www.aucklandcouncil.govt.nz/plans-projects-policies-reports-bylaws/our-plansstrategies/auckland-plan/about-the-auckland-plan/Pages/pacific-auckland.aspx
} 
Currently in Aotearoa New Zealand, at the level of government ministries, there is consistency with the use of 'Pacific' and 'Pacific peoples,' based on the respective websites of the Ministry of Health (MoH), the Ministry of Social Development (MSD), the Ministry of Business, Innovation and Employment (MBIE), and the Ministry of Pacific Peoples (MPP). However, in some ministries, if one carries out a cursory website search, alternative terms such as 'Pasifika' are used internally for some services, programmes, reports and associated groups. For example, on the $\mathrm{MoH}$ website reference is made to the Faiva Ora National Pasifika Disability Plan. In 2018, the MPP launched its Pacific Aotearoa Lalanga Fou Report. MBIE continues to run its Tupu Tai Pasifika Public Sector Summer Internship programme.

As for the MoE, it officially used the term Pasifika peoples until recently. It defined and described Pasifika education as a strategic area of work (as cited by Samu et al., 2008, p.147). Then, in 2018, it abruptly changed to using Pacific and Pacific peoples. I found this problematic. First, the literally overnight and unexplained change to 'Pacific' did not appear to recognise the accumulation of ideas, beliefs, assumptions, knowledge and understandings associated with 'Pasifika' and 'Pasifika education' that had built up over almost two decades of MoE usage and socialisation within the compulsory and early learning sectors. The internal change within the MoE would not necessarily result in automatic change in these education sectors. 'Pasifika education' had arguably became what Bacchi (2005) defined as policy as discourse - an “... institutionally supported and culturally influenced interpretive and conceptual schema[s] that produce[s] particular understandings of issues and events" (p. 199). Arguably, as a schema, many educators accepted it as the only way of understanding the education and development of Pasifika peoples. This is because the institutionalisation of Pasifika education within the MoE (facilitated by its Pasifika Education Plans, contracted research, and professional learning and development contracts) embedded Pasifika education across and within the sectors, thereby increasing its legitimacy and validity. I wish to emphasise the contestable nature of all terms, previous and current, particularly when an uncritical, ahistorical stance is taken.

Henceforth, in this essay I will use Pasifika/Pacific as a compromise between current Ministry policy and habitual practice in many early learning centres and schools. I will now chart the emergence and institutionalisation of this well-established discourse.

\section{Ad hoc origins}

One of the first academic publications identifying Pacific education as an area of focus was a chapter of a first year Education Studies textbook published by Dunmore Press in 1994. The textbook was written for use within a Bachelor of Education degree offered by the University of Auckland in partnership with the Auckland College of Education. Entitled 'Pacific Islands Education,' this chapter included a critique of educational initiatives targeting Pasifika/Pacific peoples, established and implemented over the previous two decades. The authors referred to this period of time as one in which there was "... an increasingly widening contrast between the efforts and energies of Pacific communities themselves and the ad hoc response of those in power" (Mara, Foliaki \& Coxon, 1994, p. 200).

In retrospect, this seminal chapter serves another purpose - the documentation and critique of the preliminary emergence of the education and development of Pasifika/Pacific peoples in Aotearoa New Zealand. I believe that it is as important to do this now as it was then, and for the same reasons that Mara, Foliaki and Coxon declared almost three decades ago: "An understanding of the political, social and economic context 
of Pacific Islands communities in Aotearoa is essential for interpreting the educational outcomes of this group as a whole" (Mara et al., 1994, p. 197). Si'ilata et al. (2017) have identified three progressive phases that followed in terms of the purposeful involvement and development of Pacific/Pasifika education by the New Zealand Ministry of Education. In this essay, I identify and add a fourth progressive phase.

\section{With the MOE at the helm}

\section{Phase one: Grappling with high disparities}

Si'ilata and colleagues (2017) argue that the first phase of Pacific/Pasifika education straddled the mid-1990s to late 1990s. The impetus was low-performing schools located within “... two of New Zealand's most entrenched areas of urban socioeconomic disadvantage and white/middle class flight" (Thrupp, 1998, p. 198). Matters came to a head when the Education Review Office (ERO) released a damning report in 1996 on the performance of low decile schools in South Auckland, arguing "... chronic issues of low attainment, truancy, poor teacher morale, and recruitment in these schools were caused by poor school performance" (Si'ilata et al., 2017, p. 6). Other sources, namely academic researchers, argued that these issues were due to the socio-political context and conditions schools' communities were experiencing (Thrupp, 1998). It was a context undeniably shaped by the economic recession of 1986 to 1994, set off by the 1980s economic reforms. According to Brian Easton (responsible for writing 'Economic History' for online Te Ara, Encyclopaedia of New Zealand), "Others believe that the measures caused unnecessary hardship - they speak of the conversion of 'fiscal deficit' into a social deficit."

The Ministry of Education (and other government agencies) endeavoured to make sense (via contracted education research and development projects) of pressing social and economic issues experienced in specific areas, which also coincided with the so-called poorly performing Decile One schools. The majority of the students in the affected schools were Māori and Pacific/Pasifika. Ministry of Education funded projects such as Achievement in Multicultural High Schools (AIMHI) and Strengthening Education in Mangere and Otara (SEMO) ensued.

\section{Phase two: Responding to diversity}

The second phase took place over 2000-2010 and was far more strategic compared to its reactive predecessor. Si'ilata et al. (2017) described it as “... an intensification and consolidation of state funding in national policy, research and development" (p. 6). They argue that an important driver was Aotearoa New Zealand's results from the first Programme for International Student Assessment (PISA) in 2000 by the OECD, which found that three groups of students were over-represented in the 'tail-end' of Aotearoa New Zealand's student performers: Māori, Pacific/Pasifika and special needs. Post-PISA analyses by the Ministry of Education concluded that the problem lay in part in the inability of teachers to be responsive to diverse learners. According to Alton-Lee (2004):

The high disparities, the relatively high variance within schools in the New Zealand PISA results, and our rapidly growing demographic profiles for those learners traditionally underserved by New Zealand schooling, indicate a need for community and system development to be more responsive to diverse learners. (p.8) 
The first five year Pasifika Education Plan 2001-2006 (PEP) was released (MoE, 2001), with the second, Pasifika Education Plan 2006-2010 (MoE, 2006), third Pasifika Education Plan 2008-2012 (MoE, 2008) and fourth Pasifika Education Plan 2009-2012 (MoE, 2009) released and/or rescinded in response to changes in government. For example, the second five year PEP 2006-2010 did not see its full term out. Labour revoked and relaunched it in 2008. According to Tongati'o (2010), it was part of a "concerted effort to step up" the MoEs efforts to improve education outcomes and to "extend the time frame of the plan to 2012 to align it to other key education strategies." After three terms in government, Labour lost the elections in the latter half of 2008. National revoked PEP 2008-2012 and released PEP 2009-2012. One of the reasons was to include the introduction of controversial National Standards in numeracy and literacy.

The PEP is part of what has been described as the Ministry's national policy framework for Pasifika education (Samu, 2013) - a framework crossing all sectors. It included the Tertiary Education Strategy (TES) and clear connections to the National Education Guidelines.

\section{Phase three: Embedding system development}

Si'ilata et al. (2017) described the third phase as straddling 2011-2017, and was “... characterised by a reduction in research and development contracts and a significant increase in professional learning and development (PLD) projects, informed by the evidence-based research outcomes of Phase Two" (p. 7). Phase Two being 'Responding to Diversity.'

The fifth Pasifika Education Plan 2013-2017 (MoE, 2013) guided the Ministry's efforts to influence schools and early learning centres efforts in relation to Pacific/Pasifika learners, their families and communities. This PEP steered educator attention to Pacific/Pasifika learners and their families, and embedded key discourses developed over the prior phase - that "Pasifika success" requires a focus on Pacific/Pasifika learners and their families' culture, identity and language; for teachers to practice "culturally responsive pedagogy" and the importance of nurturing interpersonal "relationships." Arguably, the re-structuring of MoE funded PLD has ensured a streamlined flow of the Ministry's construction of Pacific/Pasifika learners, their communities and the how their education is to be known, understood and delivered by teachers.

\section{Phase four: Deeper engagement}

Moving further on from Si'ilata et al. (2017), I argue that Pacific/Pasifika education has moved into its fourth progressive phase, which began after the 2017 general election when Labour became the government. In 2017, the incoming Minister of Education extended the 'life' of the fifth PEP by a year. In 2018, the Ministry of Education extended the fifth $P E P$ by another year, reassuring stakeholders that a new replacement plan for Pacific/Pasifika was still under development and would be released soon.

Early in 2018, the Minister of Education announced a three year Education Work Plan, which began with a comprehensive national conversation "... about what New Zealanders want their education system to look like" (as quoted in Education Gazette). The Work Plan recognised that there was a "... specific need for deep engagement with Māori and Pacific peoples, the disabled and those with extra learning difficulties" (Education Gazette, 2018a; emphasis added). Extensive and intensive Pacific/Pasifika community consultation over 2018 and 2019 shaped two high level national developments holding huge potential as levers of change for Pacific/Pasifika learners and 
families, particularly within the early learning and compulsory sectors. Those leading these developments appear to have collaborated and engaged with Pacific/Pasifika peoples (learners, families, professional communities and other stakeholders) at the level of national strategy and policy in ways hitherto unseen.

The first high level development was Tapasā Cultural Competencies Framework for Teachers of Pacific Learners, released in 2017 in draft form for stakeholder feedback, and finalised in August 2018. It is intend as a "tool that can be used to build the capability of all teachers of Pacific learners across all education sectors" (MoE, 2018b, p. 1). The Ministry of Education passed the responsibility for socialising this framework to all teachers within the early learning and compulsory education sectors to the Teaching Council. The Teaching Council appears to be ensuring that engaging with Tapasā is not just an option for schools, centres and teacher education providers.

The second high-level development was released in July of 2020, with the Ministry of Education's release of the Action Plan in Pacific Education: 2020-2030 (APPE) (MoE, 2020), a ten-year strategy rather than the five-year strategy that the Pasifika Education Plan had been. The APPE identifies five key system shifts: 1 . to work "reciprocally with diverse Pacific communities" in terms of needs arising from the Covid-19 pandemic, 2. to "enable every teacher, leader and educational professional" in terms of cultural competence with "diverse Pacific learners," 3. to "partner with families to design education opportunities" that lead to qualifications and in turn employment, 4. to increase numbers and build both capacity and capability of teachers with "diverse Pacific heritages," and 5. to "confront systemic racism and discrimination in education."

\section{Uncharted waters: Education and responding to racism}

I consider the identification and articulation of racism in the APPE as akin to a rogue wave - unexpected, unanticipated yet powerful in terms of Aotearoa New Zealand national education policy. The Ministry of Education (arguably) is highly conservative and nonconfrontational when it comes to recognising race and racism within national policy. 'Culture,' via the discourses of cultural difference and multiculturalism, permeated policies of difference throughout curriculum development of the 1990s (Samu, 1998, 2004). 'Diversity' was the radical replacement at the turn of the current century, heralded and then embedded by the Ministry's Iterative Best Evidence Synthesis programme (Samu, 2011). I assert that the Aotearoa New Zealand education system, and (generally speaking) its teachers, leaders and educational professionals, do not have the capacity to acknowledge and deal honestly and frankly with race and racism. Rather, it is a source of acute discomfort.

A significant feature of the 'Responding to diversity' and 'Embedding system development' phases was capacity building within the education system, based on new, contextualised evidenced-based knowledge. Regrettably, recognising and responding to racism was not explicitly coupled with the focus on culture. As Gloria Ladson-Billings (2015) explained, with reference to the United States context:

I believe that most educators do not know enough about how race and culture impact everyone's lives - the students, their parents, the community, and the educators. Lacking that understanding typically leads to a series of missteps that result in a lack of trust and ability to work together. Having the courageous and yes, hard conversations is where we begin. ( $p . x v$; emphasis added) 
It is one thing for the Ministry to recognise the need to "confront systemic racism and discrimination in education." But, to do so, there is a need to build the capacity of all sectors and all levels within the education system.

One does not need to go far to Identify the origin of this particular key shift in the APPE. Racism was an important issue that surfaced during the Ministry-driven community consultations that took place over 2018 and 2019 as part of Korero Matauranga/ Education Conversation, which kicked off the Minister's Education Work Plan. According to records from the Pacific/Pasifika focus group:

Racism is a barrier in education - the incorrect pronunciation of names, the surprise when Pacific students are smart, and the criticism of scholarships for our Pacific students. Our young people want to know how to deal with this when they are faced with it and you all want to see a more inclusive system (MoE, 2018c).

Racism, and experiencing racism in schooling, was also an issue raised by Pacific/Pasifika youth in a similarly comprehensive nationwide consultation undertaken by the Ministry of Pacific Peoples. This informed its Pacific Aotearoa: Lalanga Fou Report (MPP, 2018), launched in November 2018. A striking feature of both consultations was the extent to which Pacific/Pasifika voices were privileged. Both consultation processes positioned Pacific/Pasifika perspectives of their lived realities as authoritative. What the communities had to say went straight to the top, so to speak, to Ministers and/or Associate Ministers, by-passing any bureaucratic check points that might have diminished and diluted how their views would be reported.

Racism was an important issue in the public domain in 2017, with the Human Rights Commission launching its 'Give Nothing to Racism' campaign. The Teaching Council, working with the Human Rights Commission in late 2018, collaborated on the design and development of a professional learning tool (an app) for teachers called Unteaching Racism. The app is intended to help teachers to:

self-reflect and identify where they may need to shift their own understanding of racism, in order to better support all students to succeed. They are not teaching aids, or designed in any way for teachers to use in the classroom. ${ }^{4}$

The Teaching Council, as the professional and regulatory body for teachers in Aotearoa New Zealand, intends to support teachers to have "safe and productive conversations around racism that result in changes to behaviour and practice," making explicit connection to expected professional behaviour and practice set out in Our Code, Our Standards (2017), the product of legislative requirements. It is interesting to note that it is the Teaching Council rather than the Ministry of Education, that appears to have contributed timely leadership and direction in the uncharted waters made murky by long ignored systemic racism.

\section{Insights to shape new directions}

Our past explains our current position. It is a past that originates in Pacific-heritage community advocacy and activity in the late 1970s through the 1980s, and disjointed responses from the state. When a severe recession hit, worsening social disparities, the state's response to how the education system responded to Pasifika/Pacific learners was

\footnotetext{
${ }^{4}$ https://www.unteachracism.nz/about-unteach-racism.html
} 
primarily reactive. By the early 2000s, Pasifika/Pacific education and development had become enshrined in cabinet-approved national strategic planning and received infrastructural support (and funding) required to progress the achievement of related goals and objectives. Pacific-specific planning became institutionalised, even though the actual details of such plans were susceptible to whichever party was in government. Pasifika/Pacific population growth, and concentration in certain suburbs in Auckland and Wellington, positioned them with hitherto unseen influence as voters. The number of Pacific-heritage members of parliament after the 2020 elections currently stands at eleven, an increase from the eight that entered parliament after the 2014 elections. When Labour took over government in 2017, the Associate Minister of Education (Pacific) role was instituted for the first time. This role has continued into Labour's second term. The APPE was supported in the 2019 budget with NZD\$27.4 million, and in 2020 with NZD\$80.2 million (New Zealand Government press release).

I argue that a defining feature of the current position of Pasifika/Pacific education is a level of attentiveness and responsiveness by the Ministry of Education to community voice hitherto unseen. Pasifika/Pacific peoples have oft-times in the past been positioned as advisory, which often has little to do with effecting change. I now 'see' the rise of relationships where Pasifika/Pacific have greater influence, possibly even agency. This aspect of the current phase of 'Deep Engagement' in Pasifika/Pacific education could mean Pasifika/Pacific peoples have considerably more influence directing the development of an education system in ways that align more authentically with their aspirations.

New directions in Pasifika/Pacific education involves looking critically over the past to connect and understand the present, in order to challenge complacency, provide alternative perspectives, deepen insights and strengthen understandings amongst those actively engaged as educators, policy makers and researchers in the education and development of Pasifika/Pacific peoples in Aotearoa New Zealand. I argue that it means listening, privileging, and responding to the voices of Pasifika/Pacific peoples. It requires dedicated effort to deeply understand the issues that Pasifika/Pacific peoples raise (this requires research) and from there, build the capacity and relational spaces that will help develop what Singleton describes as "culturally proficient, racially conscious, courageous educators" (2014, p. 20). We need these same characteristics for policy makers and researchers.

\section{References}

Alton-Lee, A. (2004). Using best evidence syntheses to assist in making a bigger difference for diverse learners. Ministry of Education.

https://www.educationalleaders.govt.nz/Pedagogy-and-assessment/Building-effectivelearning-environments/Using-Best-Evidence-Syntheses-for-diverse-learners

Bacchi, C. 2005. Discourse, Discourse everywhere: Subject "Agency" in Feminist Discourse Methodology, NORA- Nordic Journal of Feminist and Gender Research, 13(3), 198-209.

Bacchi, C., \& Goodwin, S. (2016). Poststructural Policy Analysis: A Guide to Practice. Pelgrave Pivot.

Easton, B. https://teara.govt.nz/en/economic-history/print 
Foucault, M. (2002). The Archaeology of Knowledge (A. M. Sheridan Smith, Trans.) (2nd ed.). Taylor \& Francis.

Ladson-Billings, G. (2014). Foreword. In G. E. Singleton (Ed.), Courageous Conversations About Race (2nd ed.). Corwin Press.

Mara, D., Foliaki, L., \& Coxon, E. (1994). Pacific Islands education. In E. Coxon, K. Jenkins, J. Marshall, \& L. Massey (Eds.), The politics of learning and teaching in Aotearoa New Zealand. Palmerston North: Dunmore Press pp. 180-214.

Ministry of Education. (2001). Pasifika Education Plan 2001-2006.

Ministry of Education. (2006). Pasifika Education Plan 2006-2010.

https://www.mcguinnessinstitute.org/wp-content/uploads/2021/04/140.-

Pasifika Education Plan 2006-2010.pdf

Ministry of Education. (2008). Pasifika Education Plan 2008-2012.

https://www.mcguinnessinstitute.org/wp-content/uploads/2021/04/144.-PasifikaEducation-Plan-2008-2012.pdf

Ministry of Education. (2009). Pasifika Education Plan 2009-2012.

https://www.mcguinnessinstitute.org/wp-content/uploads/2021/04/146.-PasifikaEducation-Plan-2009-2012.pdf

Ministry of Education. (2013). Pasifika Education Plan 2013-2017.

https://education.govt.nz/assets/Documents/Ministry/Strategies-and-

policies/PasifikaEdPlan2013To2017V2.pdf

Ministry of Education. (2018a). Government releases its three-year education work programme. Education Gazette, 97(4).

https://gazette.education.govt.nz/articles/government-releases-its-three-yeareducation-work-programme/

Ministry of Education. (2018b). Tāpasa: Cultural competencies framework for teachers of Pacific learners. https://teachingcouncil.nz/resource-centre/tapasa/

Ministry of Education. (2018c). What you said: 2018 Fono. Education Conversation / Korereo Matauranga. https://conversation.education.govt.nz/conversations/actionplan-for-pacific-education/what-you-said-2018-fono/

Ministry of Education. (2020). Action Plan for Pacific Education 2020-2030.

https://conversation.education.govt.nz/conversations/action-plan-for-pacificeducation/

Ministry for Pacific Peoples. (2018). Pacific Aotearoa Lalanga Fou. https://www.mpp.govt.nz/assets/Uploads/Pacific-Aotearoa-Lalanga-Fou.pdf 
Organisation for Economic Co-operation and Development (OECD). (2005). The definition and selection of key competencies: Executive summary. https://www.oecd.org/pisa/35070367.pdf

Samu, T. W. (1998). Social Studies: The nebulous Cinderella subject of the New Zealand school curriculum (Unpublished Master's thesis). University of Auckland.

Samu, T. W. (2004). Multiple lenses, multiple ways of seeing our world: Some critical reflections. In New Zealand Journal of Social Studies, 12(1), 8-13.

Samu, T. W., Mara, D., \& Siteine, A. (2008). Education for Pacific Peoples, for the $21^{\text {st }}$ Century' in Nga Kaupapa Here: connections and contradictions in education. Edited by V. Carpenter, M. Stephenson, P. Roberts and J. Jesson. Thompson Publishers.

Samu T. W. (2010). Pasifika education: An oceanic perspective. In Pacific research in education: New directions. MAI Review, Issue 10.

http://www.review.mai.ac.nz/mrindex/MR/article/download/311/311-2283-1-PB.pdf

Samu, T. W. (2011) Understanding the lines in the sand: Diversity, its discourses and building a responsive education system. In Curriculum Matters, Vol. 7. NZCER.

Samu, T. W. (2013). Pasifika Education: Discourses of Difference Within Education in Aotearoa New Zealand Education. (Unpublished Doctoral thesis). University of Canterbury.

Sawyer, R.K. (2002). A Discourse on discourse: An archaeological history of an intellectual concept. Cultural Studies 16(3) 433-456.

Si'ilata, R., Samu, T. W., Siteine, A. (2017). The Va'atele Framework: Redefining and Transforming Pasifika Education. In: McKinley E., Smith L. (Eds.) Handbook of Indigenous Education. Springer.

Singleton, G. E. (2014). Courageous Conversations About Race (2nd ed.). Corwin Press.

Teaching Council of Aotearoa New Zealand. (2017). Our Code, Our Standards: Code of Professional Responsibility, Standards for the Teaching Profession.

https://teachingcouncil.nz/assets/Files/Code-and-Standards/Our-Code-Our-StandardsNga-Tikanga-Matatika-Nga-Paerewa.pdf

Thrupp, M. (1998). Exploring the politics of blame: School inspection and its contestation in New Zealand and England. Comparative Education, 34(2), 195-209.

Tongati'o, L. (2010). Ko o e Fana Fotu: Success in Motion, Transforming Pasifika Education in Aotearoa New Zealand 1993-2009. (Unpublished Doctoral thesis). University of Canterbury. 
Dr Tanya Wendt Samu is a senior lecturer in the School of Critical Studies in Education, Faculty of Education, University of Auckland. Tanya's research and scholarship has focused on Pacific/Pasifika education and Pacific research in education, in addition to curriculum development (Social Studies, Social Sciences) for over twenty years.

Email: t.samu@auckland.ac.nz

ORCiD: https://orcid.org/0000-0003-3451-0247 